\title{
La noticia y la entrevista. Una aproximación a su concepto y estructura
}

\author{
Dr. Rafael Yanes Mesa \\ Universidad de La Laguna
}

\section{RESUMEN}

El periodismo informativo tiene como único fin la información, y en su estilo destacan como características esenciales la claridad, la sencillez y la exactitud. Hay dos géneros periodísticos que responden principalmente a estos criterios: la noticia y la entrevista.

Ambas tienen como sello de identidad su función informativa, aunque entre las entrevistas debe contemplarse una modalidad que se aproxima al artículo, ya que, sin abandonar su fin informativo, incorpora un componente estético: la entrevista creativa.

\section{ABSTRACT}

The informative journalism has as only aim the information, and in its style highlight as essential characteristic the clarity, the simplicity, and the accuracy. There are two journalistic genres that mainly they respond to these approaches: the news and the interview.

Both have as hallmark of identity their informative function, although among the interviews a modality should be contemplated that approaches to the article, although, without abandoning its informative end, it incorporates an aesthetic component: the creative interview.

Palabras claves: Ciencias de la Información/Periodismo/Géneros periodísticos.

Key words: Information Sciences/Journalism/Journnalistic genres.

\section{El periodismo informativo}

uchos autores diferencian entre los géneros periodísticos interpreta-
tivos y los de opinión, al considerar que la interpretación tiende
hacia la objetividad, mientras que los segundos son textos con
subjetividad real. Otros afirman que la interpretación no es un criterio que distinga ningún grupo concreto de géneros porque cuando aparece de forma explícita equivale a opinión, y la interpretación implícita está siempre en todo escrito periodístico. Pero en lo que hay unanimidad es en distinguir claramente los géneros del periodismo informativo. 
Si, como dice José Acosta Montoro, el periodismo es la historia del presente y la historia es el periodismo del pasado ${ }^{1}$, podríamos concluir con que en el periodismo sólo cabe relatar los sucesos acaecidos recientemente que tienen interés general. Desde este punto de vista, el periodismo sería únicamente información, y su contenido se limitaría al relato frío e imparcial de lo que ocurre. Pero no todo lo que contienen los periódicos son trabajos con un fin exclusivamente informativo. Luis Núñez Ladevéze afirma que la producción periodística no es "ni exclusivamente ni principalmente informativa"2.

Una parte del periodismo, que denominamos periodismo informativo, es la que tiene como único fin la información. Guillermina Baena Paz lo define como el que se dedica solamente al relato escueto del suceso ${ }^{3}$, pues no tiene otra función que la de comunicar con imparcialidad lo ocurrido, es decir, contar a la sociedad, con un lenguaje directo y sencillo, aquellos acontecimientos que pudieran ser de su interés. Ana Francisca Aldunate y María José Lecaros consideran que se basa en un relato breve y esquemático de los acontecimientos ocurridos recientemente, donde lo importante es contar, de la forma más concisa, breve y clara posible, un hecho verdadero, inédito, de actualidad, y de interés general ${ }^{4}$.

\subsection{Objetividad inalcanzable... e irrenunciable}

La objetividad es su carta de presentación, que consiste en la expresión sincera y no interesada de lo que se considera cierto o verdadero ${ }^{5}$. Objetividad posiblemente inalcanzable en el fondo, pues, como dice Fattorello ${ }^{6}$, la información siempre es subjetiva, ya que marcha con la naturaleza humana y con el momento en el cual se produce, por lo que el hombre no puede salirse de sí mismo, de su subjetividad, ni de la contingencia de los acontecimientos que vive. Enrique Castejón Lara afirma que los resultados de los estudios psicológicos han demostrado la incapacidad del hombre para despojarse de sus sentimientos, prejuicios y valores a la hora de reflejar y de percibir un texto ${ }^{7}$. Además, hace una distinción entre tres palabras que suelen ser utilizadas como sinónimas, aunque tienen importantes diferencias conceptuales y semánticas: objetividad, veracidad e imparcialidad. La primera se encuentra íntimamente relacionada con la fría rigurosidad sin añadidos de opinión personal, pero ni siquiera el hecho de que una noticia haya sido redactada con este principio da garantías de que sea veraz, y mucho menos imparcial ${ }^{8}$.

\footnotetext{
1 Vid. Periodismo y literatura. Guadarrama, Madrid, 1999, Volumen I, página 56.

2 Vid. Introducción al periodismo escrito. Ariel Comunicación, Barcelona, 1995, página 21.

3 Vid. Géneros periodísticos informativos. Pax México, México D.F., 1990, página 35.

4 Vid. Géneros Periodísticos. Pontificia Universidad Católica de Chile, Santiago de Chile, 1989, página 19.

5 Vid. Muñoz González, José Javier: Redacción periodística. Librería Cervantes, Salamanca, 1994, página 29.

6 Cfr. Río Reynaga, Julio del: Teoría y práctica de los géneros periodísticos informativos. Diana, México D.F., 1991, página 47.

7 Vid. La verdad condicionada. Corprensa, Baruta (Venezuela), 1992, página 25.

8 Ibídem, página 33.
} 
El camino más corto para poder ser objetivo es la independencia, y la publicidad en los periódicos es un factor importante de financiación que puede condicionar al medio. Montserrat Quesada recuerda que el periodismo es un negocio, aunque no debe olvidar su función social. Toda empresa informativa pretende elaborar un buen producto para que llegue al mayor número de lectores, $\mathrm{y}$, como consecuencia, genere los mayores beneficios económicos, por lo que ambas funciones, el negocio y el interés público, pueden resultar incompatibles. Sin embargo, la objetividad puede convertirse en un recurso de apertura para el incremento de prestigio que incluso puede producir una mayor tirada ${ }^{9}$. Desde esta perspectiva, la objetividad periodística podría traducirse en rentabilidad económica.

Para José R. Vilamor, la objetividad es como la virtud, es decir, un fin a perseguir siempre, aunque se sepa que no se logra nunca ${ }^{10}$. Josep Lluis Gómez Mompart habla de "la falacia de la objetividad periodística"11, expresión que también utiliza María Pilar Diezhandino al estudiar la objetividad en la historia y en el periodismo ${ }^{12}$. Más contundentes se muestran Sebastiá Bernal y Lluis Albert Chillón, quienes señalan que ningún mensaje informativo puede ser objetivo, apolítico, imparcial, neutral e independiente porque su emisor, en el acto de selección de los datos informativos, del registro, elaboración y transmisión, discrimina, ordena, manipula e incluso interpreta la realidad que pretende comunicar a su auditorio ${ }^{13}$. Y Marguerite Duras ${ }^{14}$ insiste en la imposible objetividad periodística, que califica como "mentira", pues desde el momento en que se seleccionan las informaciones, la subjetividad es patente.

Si aceptamos que es imposible la objetividad, se impone la honesta subjetividad. Álex Grijelmo así lo considera al afirmar que no existe la objetividad pura, pero sí la honradez pura $^{15}$. En la honestidad incide Manuel López cuando define al periodista como un profesional que tiene una base cultural muy sólida adquirida en la universidad-, que domina las técnicas periodísticas y que está dotado de criterios personales basados en la honestidad y el respeto a la verdad cuando relata los hechos ${ }^{16}$. Y también el profesor Martínez Albertos, quien considera que el concepto de periodismo descansa en dos campos: su fin social y la exigencia de una honestidad intelectual en el emisor de mensajes ${ }^{17}$, al igual que

9 Vid. La investigación periodística. Ariel Comunicación, Barcelona, 1987, página 59.

10 Vid. Redacción periodística para la generación digital. Universitas, Madrid, 2000, página 230.

11 Vid. Los titulares en Prensa. Editorial Mitre, Barcelona, 1982, página 9.

12 Vid. El quehacer informativo. Servicio Editorial de la Universidad del País Vasco, Bilbao, 1994, página 123.

13 Vid. Periodismo informativo de creación. Mitre, Barcelona, 1985, página 13.

14 Cfr. Abril Vargas, Natividad: Periodismo de opinión. Síntesis, Madrid, 1999, página 25.

15 Vid. El estilo del periodista. Grupo Santillana de Ediciones, Madrid, 2001, página 561.

16 Vid. López, Manuel: Cómo se fabrican las noticias. Ediciones Paidós, Barcelona, 1995, página 59.

17 Vid. Martínez Albertos, José Luis: El lenguaje periodístico. Editorial Paraninfo, Madrid, 1989, página 133. 
Guillermina Baena Paz, para quien las cualidades del periodista son la honestidad, la objetividad, la responsabilidad, el espíritu de lucha y la modestia ${ }^{18}$.

\subsection{El estilo informativo}

Los géneros periodísticos que consideramos dentro del periodismo informativo, con la función única de informar, tienen unas características propias que no son las del periodismo en general. En primer lugar, responden a la realidad de lo que ha ocurrido, y no es producto de la fantasía de su autor, pues se trata de comunicar algo concreto de forma directa, y sin ningún añadido que pudiera distorsionar la interpretación del hecho acontecido por parte del receptor. En un género de periodismo informativo tampoco se incluye la opinión del periodista, aunque autores como Lester Markel ${ }^{19}$ creen que la interpretación es un elemento básico en las tareas informativas, y que esta función debe ser considerada como un juicio objetivo basado en los antecedentes del hecho noticiable. De esta forma, la interpretación, y no la opinión, sería parte esencial del periodismo informativo, y, por tanto, siempre se incluiría. Lo mismo piensa Luis Núñez Ladevéze, quien afirma que en todo género periodístico informativo implícitamente siempre hay interpretación, ya que el modo de presentar una noticia implica una previa valoración de su importancia social ${ }^{20}$.

La revista Time estima que la interpretación periodística tiene una función informativa, y debe cumplir cuatro requisitos básicos ${ }^{21}$ : Clarificación, en cuanto deben incorporarse detalles de la personalidad del sujeto y ambiente protagonistas de la noticia; Perspectiva, que sitúa el suceso en su contexto temporal; Significación, en cuanto a la importancia con respecto a otras situaciones; y Consecuencia, que valora los posibles efectos que a raíz de este suceso se pueden producir.

Son mensajes que están dirigidos al gran público, por lo que el uso de un vocabulario sencillo es fundamental. Pero sencillez no significa vulgaridad. Se trata de utilizar términos comunes que sean asequibles para la gran mayoría, no de palabras "populacheras", que además no añaden comprensión. Como consecuencia de ello, su lenguaje puede ser, en ocasiones, pobre desde el punto de vista estético, ya que su objetivo es que resulte siempre enormemente claro para su rápido entendimiento. Por ello, la riqueza de vocabulario es limitada, con el consiguiente riesgo de perder exactitud.

Núñez Ladevéze opina que es la sencillez el objetivo al que debe orientarse todo mensaje informativo para lograr una correcta comunicación. Para este autor,

18 Vid. Géneros periodísticos informativos. Op. cit. página 29.

19 Cfr. Santamaría Suárez, Luisa: El comentario periodístico. Los géneros persuasivos. Editorial Paraninfo, Madrid, 1990, página 20.

20 Vid. Introducción al periodismo escrito. op. cit. página 33.

21 Vid. Aldunate, Ana Francisca y María José Lecaros: Géneros Periodísticos. Op. cit. página 31. 
la claridad y la corrección no se encuentran en lo más fácil, en lo más simple, ni tampoco en el término medio entre lo fácil y lo difícil, sino en "el modo más fácil de expresar lo más difícil" ${ }^{22}$. También Octavio Aguilera ${ }^{23}$ hace hincapié en que el objetivo del periodismo informativo es lograr la comprensión del mensaje para el gran público, cuando afirma que el periodista trabaja contrarreloj para que el mensaje interese a todos, llegue a todos, y sea lo más útil, fácil, directo y comprensible para todos. Si el texto está redactado con la suficiente claridad, consigue su verdadero fin, pues, como dice Núñez Ladevéze, la comprensión es el premio que se concede a quienes se esfuerzan por alcanzarla ${ }^{24}$, y es la adecuación del mensaje informativo lo que puede otorgar la debida comprensión.

En palabras de Tobías Peucer ${ }^{25}$, autor de la primera Tesis Doctoral sobre periodismo (De relationibus novellis, Leipzig, 1690), el estilo de los periódicos no ha de ser oratorio ni poético, porque aquél aleja al lector apasionado por la novedad que tiene la actualidad, y éste le causa confusión y no expone las cosas con la suficiente claridad. El periodista, si desea ser eficaz, tiene que ser entendido en el acto. Si es necesario una relectura, es que no ha sido elaborado con la suficiente claridad, y que el léxico utilizado no es el adecuado, por culteranismo, o el mensaje inapropiado, por conceptismo. Joaquín Garrido afirma que para conseguir que el lector comprenda el mensaje, la clave es la idea maestra de la retórica, que no es otra que la adecuación del mensaje informativo ${ }^{26}$.

Son muchos lo autores que afirman que el periodismo informativo debe estar construido con claridad y sencillez. Luis Alberto Hernando Cuadrado considera que el discurso periodístico, para lograr sus objetivos, debe caracterizarse por la claridad, precisión, fluidez, y poder de captación del lector ${ }^{27}$, al igual que Fernando García Núñez, para quien el estilo informativo es la modalidad periodística por excelencia, y considera que las tres características que debe cumplir son: concisión, claridad y captación del lector ${ }^{28}$. En la misma línea se muestran Susana González Reyna, quien plantea tres condiciones para el buen estilo informativo periodístico: brevedad, claridad y sencillez ${ }^{29}$, y Emil Dovifat ${ }^{30}$ al sintetizar las características que debe cumplir el estilo periodístico informativo en tres aspectos: concisión, claridad y una construcción que capte la atención del lector.

22 Vid. Métodos de redacción periodística y Fundamentos de estilo. Síntesis, Madrid, 1993, página 33.

23 Cfr. López García, Ángel: Escritura e información. Editorial Cátedra, Madrid, 1996, página 12.

24 Vid. Métodos de redacción periodística y Fundamentos de estilo. Op. cit. página 33.

25 Cfr. López García, Ángel: Escritura e información. Op. cit. página 13.

26 Vid. Idioma e información. La lengua española de la comunicación. Síntesis, Madrid, 1994, página 167.

27 Vid. El discurso periodístico. Verbum, Madrid, 2000, página 87.

28 Vid. Cómo escribir para la prensa. Ibérico Europea de Ediciones, Madrid, 1985, página 26.

29 Vid. Géneros periodísticos 1. Periodismo de opinión y discurso. Editorial Trillas, México D. F., 1991, página 26.

30 Cfr. Martínez Albertos, José Luis: Curso general de redacción periodística. Op. cit. página 317. 
Sebastiá Bernal y Lluis Albert Chillón señalan tres propiedades que debe cumplir un texto para ser considerado como género del periodismo informativo: que sea un relato de no ficción, que carezca de innovación formal y expresiva, y que no tenga carácter argumentativo ${ }^{31}$. Son géneros cuyo texto refleja lo que ha sucedido exactamente, aunque ello suponga una limitación expresiva, y la argumentación, tan propia de algunos géneros periodísticos, como la crónica o el reportaje, no tiene cabida en el periodismo informativo. Debe aproximarse a lo que Víctor Rodríguez denomina "estilo expositivo", que es la forma de expresar unos conocimientos como si se tratara de un examen, de manera que el texto contenga todo lo que queremos transmitir, sin añadidos innecesarios ${ }^{32}$.

Pero esto no significa que el estilo propio del periodismo informativo tenga que ser monótono y aburrido. Debe expresarse con un lenguaje ágil, variado y con ritmo, de manera que el lector se vea atraído por el texto hasta el final del relato. Y, por supuesto, siempre debe estar construido correctamente desde el punto de vista gramatical. El buen periodista tiene que dominar con bastante corrección las reglas del idioma. El exacto cumplimiento de las estructuras formales de la lengua tiene que ser una máxima irrenunciable, y que posiblemente debiera estar recogido en los códigos deontológicos del periodismo. López García afirma que cuanto más depurado sea el estilo de un texto periodístico de cualquier género, más se adecuará a la finalidad para la que fue concebido, y mejor logrará sus objetivos ${ }^{33}$.

José R. Vilamor considera que el lenguaje periodístico tiene unas características que lo diferencian de otros géneros literarios. Enumera diecisiete condiciones que debe reunir todo mensaje informativo ${ }^{34}$ : brevedad, claridad, concisión, una sola idea, transición lógica, no ser erudito, precisión, originalidad, ironía, diálogo y sinceridad, persuasión, variedad, atracción, ritmo, color, detallismo y optimismo.

La claridad se caracteriza por el uso de verbos activos y dinámicos en forma activa $^{35}$, pero, además, el texto tiene que estar construido con un lenguaje sencillo, y esto nos lleva a otra condición indispensable: la exactitud. Se deben evitar los términos con amplio significado, y emplear las palabras justas para comunicar los conceptos concretos. Para Núñez Ladevéze, la claridad depende del uso de palabras de poca densidad porque son las más comprensibles para los hablantes y las que menor esfuerzo interpretativo exigen ${ }^{36}$.

Gonzalo Martín Vivaldi manifiesta que hay cuatro características fundamentales en el buen estilo periodístico: claridad, que no es superficialidad; concisión,

\footnotetext{
31 Vid. Periodismo informativo de creación. Op. cit. páginas 111 y 112.

32 Vid. Manual de redacción. Paraninfo, Madrid, 1991, página 184.

33 Vid. Escritura e información. Op. cit. página 12.

34 Vid. Redacción periodística para la generación digital. Op. cit. página 91 y siguientes.

35 Vid. Martínez Albertos, José Luis: Curso general de redacción periodística. Mitre, Barcelona, 1983, página 226.

36 Vid. Introducción al periodismo escrito. Op. cit. página 141.
} 
pero no laconismo; sencillez, no vulgaridad; y naturalidad, pero no ordinariez ${ }^{37}$. Pero este mismo autor se extiende en detallar hasta dieciséis características, que en su opinión definen el estilo periodístico informativo ${ }^{38}$ : claridad, concisión, densidad, exactitud, precisión, sencillez, naturalidad, originalidad, brevedad, variedad, atracción, ritmo, color, sonoridad, detallismo, corrección y propiedad. Son condiciones que se podrían mencionar, en negativo, con los defectos que deben ser evitados. Son lo contrario a lo manifestado, que el mismo autor nos los resume asi $^{39}$ :

la oscuridad de pensamiento y de expresión; la verborrea poco significante; la inexactitud y la vaguedad en la expresión; la imprecisión en la estructura de la frase; lo artificioso y rebuscado, en la elección de la palabra y construcción de la frase; la afectación; la vulgaridad; la innecesaria amplitud; la monotonía; la torpeza expresiva; el tono gris o incoloro; la arritmia; la cacofonía y la incorrección gramatical.

En los géneros de periodismo informativo es necesario que el lenguaje sea conciso. Deben utilizarse sólo las palabras estrictamente necesarias, y evitar a toda costa la repetición de conceptos que no aporten mayor claridad al texto. La concisión se consigue con las palabras indispensables para expresar lo que se quiere decir sin posibilidad de equívocos, por lo que es conveniente el uso de frases cortas apoyadas en el núcleo nominal en lugar del verbal, para imprimir el carácter objetivo del discurso con claridad expositiva.

José Javier Muñoz señala seis cualidades que considera imprescindibles para un adecuado texto periodístico de carácter informativo ${ }^{40}$ : claridad, fluidez, equilibrio, expresividad, corrección gramatical y adecuación al género; y el profesor Martínez Albertos menciona otras seis que coinciden, en parte, con las anteriores ${ }^{41}$ : concisión, con el uso de sintagmas nominales para lograr frases cortas; corrección, al utilizar un lenguaje próximo a la lengua coloquial culta; claridad, con el uso de verbos en forma activa; captación del interés del lector, ya que es objetivo primordial atraer la atención desde la primera línea; lenguaje de producción colectiva, por ser textos en los que colaboran diferentes profesionales; y lenguaje mixto, al concurrir distintas partes que responden a una diversidad de códigos. Este autor, siete años más tarde, en una obra conjunta con Luisa Santamaría $^{42}$, sustituye las dos últimas características por rigor informativo, que

37 Vid. Curso de redacción. Editorial Paraninfo, Madrid, 1986, página 258 y siguientes.

38 Vid. Géneros periodísticos. Paraninfo, Madrid, 1998, página 29 y siguientes.

39 Ibídem, página 37.

40 Vid. Redacción periodística. Op. cit. página 167 y 168.

41 Vid. El lenguaje periodístico. Op. cit. página 80.

42 Vid. Manual de estilo. Instituto de Prensa de la Sociedad Interamericana de Prensa, Indianápolis, 1996, página 108 y siguientes. 
tiene que ver con la exactitud de los datos utilizados en el texto, y rapidez, que justifica por la urgencia con la que se trabaja en el periodismo, algo en lo que incide también Miguel Delibes ${ }^{43}$, para quien el periodismo es la literatura "con el agobio del cierre".

En todos los casos está presente la claridad como condición necesaria para una adecuada comunicación. Álex Grijelmo llega a afirmar que "el estilo periodístico es la claridad", pues todo texto informativo debe esculpirse sin ambigüeda$\operatorname{des}^{44}$, y en la misma línea se muestra Mauricio Gallardo Mendoza cuando dice que la única exigencia imprescindible que debe cumplir un escrito con estilo periodístico es la claridad ${ }^{45}$.

En opinión de Julio del Río, en los géneros informativos el periodista se limita a relatar sin comentarios propios o ajenos. Sólo se dedica a describir con fidelidad el objeto de la información. La noticia y la entrevista son los dos géneros que se ofrecen al lector como textos imparciales, al menos sin interpretación explícita. Están redactados con una calculada apariencia objetivadora, pues el uso de un determinado estilo periodístico no implica necesariamente la imparcialidad de quien lo utiliza ${ }^{46}$. La dualidad entre el estilo y el mensaje, o, lo que es lo mismo, entre la forma y el fondo, es confusa para el lector, que puede encontrar un texto con formalismo aséptico pero con un fondo persuasivo que se dirige de forma sutil hacia una forma de entender lo sucedido. Pero persuadir no es lo mismo que manipular. Para Susana González Reyna, la diferencia está en el campo de la ética: la persuasión es un proceso de convencimiento hecho con honestidad, mientras que la manipulación es un razonamiento que busca la emotividad para modificar la conducta de un individuo en favor de unos intereses ajenos ${ }^{47}$. Para esta autora, además de diferenciarse por su estilo, los géneros del periodismo informativo lo hacen por su discurso, y considera que éste es el criterio que los define, y distingue los textos con discurso expositivo, como la nota informativa; el descriptivonarrativo, como la entrevista; el narrativo, como la crónica; y el que combina las formas narrativa y descriptiva, como el reportaje $\mathrm{e}^{48}$.

Pero los géneros que más identificados con el periodismo informativo, con las características descritas en este apartado, son dos: la noticia y la entrevista. Antonio López Hidalgo coincide al afirmar que la noticia y la entrevista son los géneros más genuinamente informativos, y considera que son los que más están

43 Cfr. Antonio López Hidalgo: La entrevista periodística. Entre la información y la creatividad. Libertarias, Madrid, 1997, página 26.

44 Vid. El estilo del periodista. Op. cit. página 300.

45 Vid. Vid. Rozas Ortúzar, Eliana (edit): Estilo periodístico. Pontificia Universidad Católica de Chile, Santiago de Chile, 1988, página 31.

46 Vid. Casasús Gurí, Josep y Núñez Ladevéze: Estilo y géneros periodísticos. Ariel Comunicación, Barcelona, 1991, página 104.

47 Vid. Géneros periodísticos 1. Periodismo de opinión y discurso. Op. cit. página 17.

48 Ibídem, página 25 y siguientes. 
obligados a responder a las seis cuestiones de rigor: qué, quién, dónde, cómo, cuándo y por qué ${ }^{49}$, además de respetar la estructura de la pirámide invertida, que en opinión del profesor Martínez Albertos, es uno de los rasgos diferenciales del periodismo informativo. Sin embargo, como veremos más adelante, la entrevista no cumple esta segunda condición. El periodismo informativo se construye con lo más importante en la primera línea para luego descender gradualmente en importancia sólo en la noticia, e incluso, en algunos medios, ni siquiera en ésta.

\section{La noticia}

Van Dijk considera que en el uso cotidiano de la palabra noticia se observan tres conceptos diferenciados ${ }^{50}$ : como una nueva información sobre sucesos, objetos o personas; como un programa tipo (de televisión o radio) en el cual se presentan ítems periodísticos; y como un ítem o informe periodístico, como por ejemplo un texto o discurso en la radio, en la televisión o en el diario, en el cual se ofrece una nueva información sobre sucesos recientes. En el presente apartado estudiaremos la noticia en su tercera acepción, es decir, como información sobre sucesos de actualidad, y, más concretamente, la noticia en prensa, es decir, los escritos publicados en los periódicos sobre hechos de interés público sin que contengan opinión ni interpretación.

Gonzalo Martín Vivaldi prefiere el término noticia, mientras que González Reyna lo llama nota informativa, y José Luis Martínez Albertos se inclina por denominarlo información, aunque la define como la noticia de un hecho con la explicación de sus circunstancias y detalles expuestos en orden inverso a su interés ${ }^{51}$. María Pilar Diezhandino ${ }^{52}$ y Fernando García Núñez también prefieren llamarlo información, género al que éste último define como la transmisión de una noticia $^{53}$. Para estos autores, la noticia es el hecho noticiable, mientras que la comunicación a los lectores es la información. En cualquier caso, el nombre más aceptado es el primero, y, aunque David Randall ${ }^{54}$ dice que definiciones de noticia hay tantas como noticias, sin incorporar demasiadas vamos a reflejar aquí lo que piensan de este género algunos de los autores que más lo han estudiado.

Julio del Río considera que la noticia es el núcleo de la información, y aporta una definición lacónica, y, posiblemente bastante acertada si se refiere al periodismo informativo, al definirla como "la célula del periodismo". Una idea que Gonzalo Martín Vivaldi comparte al afirmar que el periodismo es un nuevo género

49 Vid. La entrevista periodística. Entre la información y la creatividad. Op. cit. página 31.

50 Vid. La noticia como discurso. Piados Comunicación, Barcelona, 1990, página 17.

51 Vid. Curso general de redacción periodística. Op. cit. página 298.

52 Vid. El quehacer informativo. Op. cit. página 85.

53 Vid. Cómo escribir para la prensa. op. cit. página 40.

54 Cfr. Vilamor, José R.: Redacción periodística para la generación digital. Op. cit. página 128. 
literario que nace alrededor de la noticia ${ }^{55}$. Guillermina Baena Paz, en la misma línea, la define como la materia prima con que se hace el periodismo ${ }^{56}$, y Jesús González Requena ajusta un poco más esta definición al considerar que la noticia es la unidad narrativa nuclear de un relato informativo ${ }^{57}$, al igual que María Pilar Diezhandino $^{58}$, quien añade que la noticia, a su vez, tiene una materia prima compuesta por cuatro elementos distintos que a menudo son utilizados como sinónimos $^{59}$ : hechos que implican novedad informativa, pero no necesariamente son de actualidad; sucesos que se refieren a la actualidad del momento; asuntos que dependen de la iniciativa del periodista, pero no están condicionados por la novedad ni por la actualidad; y acontecimientos, que son hechos de gran trascendencia.

Quilis ${ }^{60}$ señala dos condiciones para que un texto pueda considerarse noticia como género periodístico: que sea de actualidad y tenga interés social, mientras que Baena Paz afirma que debe reunir cuatro: novedad, actualidad, proximidad e interés general ${ }^{61}$. Para esta autora, noticia es un acontecimiento actual que interesa a un gran número de personas que no tienen conexión con el suceso que es objeto de la información, mientras que para Vilamor es el género más periodístico, e insiste en el necesario interés social al definirla como el texto informativo por excelencia que da cuenta de un hecho actual o actualizado, o de un hecho futuro razonadamente previsto y de innegable interés público ${ }^{62}$.

Julio del Río piensa que noticia no es lo que acontece, sino que se produce cuando el periodista cuenta lo que ha sucedido. Afirma que el suceso con valor de noticia es aquel que rompe o altera el statu quo, y la noticia es un relato de ese suceso $^{63}$. José Javier Muñoz coincide en que es la información de los hechos la integrante real de este género, al afirmar que la noticia es el conjunto de datos esenciales de cualquier acontecimiento o ideas actuales o actualizados que posean factores de interés periodístico y proyección pública ${ }^{64}$.

Pero además, la noticia es un texto que posee características propias que lo definen como género diferenciado. Fernando Martínez Vallvey considera que no es la información de lo sucedido, sino un escrito que tiene unas singularidades que lo distinguen de los demás géneros. Es un determinado tipo de texto, no el hecho de que un acontecimiento sea publicado en un medio informativo ${ }^{65}$. Para este

55 Vid. Géneros periodísticos. Op. cit. página 249.

56 Vid. Géneros periodísticos informativos. op. cit. página 93.

57 Vid. El espectáculo informativo Akal Comunicación, Madrid, 1989, página 30.

58 Vid. El quehacer informativo. Op. cit. página 41.

59 Ibídem, página 44.

60 Cfr. Rodríguez Jiménez, Víctor: Manual de redacción. Op. cit. página 155.

61 Vid. Géneros periodísticos informativos. Op. cit. página 96.

62 Vid. Redacción periodística para la generación digital. Op. cit. página 152.

63 Vid. Teoría y práctica de los géneros periodísticos informativos. Op. cit. página 43.

64 Vid. Redacción periodística. Op. cit. página 93.

65 Vid. Herramientas periodísticas. Librería Cervantes, Salamanca, 1996, página 71. 
autor, la noticia es el relato que posee un modelo textual diferenciado, que se difunde a través de los medios de comunicación, que narra o expone hechos o ideas novedosas de actualidad y que presuntamente pueden interesar a la población ${ }^{66}$. En la misma línea se muestra Luis Núñez Ladevéze, que considera que la noticia no sólo es un conjunto de datos, pues para comunicarlos a otras personas es necesario que sean tratados, elaborados y ordenados de acuerdo a unas reglas textuales que conforman el género ${ }^{67}$.

Josep María Casasús integra todos los factores mencionados por los anteriores, y ofrece una definición que posiblemente es la más completa. En su opinión, la noticia como género periodístico es la manifestación última más frecuente del proceso de semantización aplicado a la información de hechos reales y actuales con interés público, y que son susceptibles por sus características de ser incorporados a los medios de comunicación social ${ }^{68}$.

Pero además, como género periodístico informativo, se caracteriza por el estilo lingüístico con el que está confeccionado. Fernando Lázaro Carreter ${ }^{69}$ afirma que el lenguaje periodístico debe aspirar a ser el que utiliza una comunidad de hablantes de un nivel culto, y debe estar construido con unos elementos característicos que lo diferencian de los textos literarios. Este autor determina los tres errores principales del lenguaje periodístico que alejan al texto del fin informativo que debe perseguir: el lenguaje literario, el lenguaje administrativo y el lenguaje de base oral.

Para Víctor Rodríguez, la noticia es el género que cumple unas determinadas cualidades que perfilan su estilo periodístico ${ }^{70}$. En su opinión, la noticia debe cumplir siete características: verdad, actualidad, interés, curiosidad, novedad, claridad y brevedad, y Carl N. Warren ${ }^{71}$ también aporta como definición la enumeración de elementos característicos que componen la sustancia de este género periodístico: actualidad, proximidad, prominencia, curiosidad, conflicto, suspense, emoción y consecuencias. Luis Alberto Hernando Cuadrado las reduce a cinco: actualidad, novedad, veracidad, periodicidad e interés público ${ }^{72}$, mientras que Gonzalo Martín Vivaldi señala que la noticia debe ser veraz, exacta, interesante, completa, clara y breve ${ }^{73}$.

66 Ibídem, página 13.

67 Vid. Introducción al periodismo escrito. Op. cit. página 15.

68 Vid. Iniciación a la periodística. Editorial Teide, Barcelona, 1988, página 107.

69 Cfr. Santamaría Suárez, Luisa: El comentario periodístico. Los géneros persuasivos. Op. cit. página 21.

70 Vid. Manual de redacción. Op. cit. páginas 155 y 156.

71 Cfr. Vilamor, José R.: Redacción periodística para la generación digital. Op. cit. páginas 131 y 132.

72 Vid. El discurso periodístico. Op. cit. página 18.

73 Vid. Curso de Redacción. Op. cit. páginas 352 y 353. 
Van Dijk afirma que el discurso periodístico utilizado en la noticia se caracteriza por cinco condiciones básicas en su estilo ${ }^{74}$ :

1. Existe una distancia entre su autor, un periodista que actúa como mediador, y el lector, que se traduce en evitar el uso de la primera persona.

2. La elección del vocabulario está preestablecida por el tema, que a veces implica palabras técnicas o jergas, por lo que no depende del autor.

3. El estilo periodístico es formal y se evitan los coloquialismos, por lo que se utilizan con profusión oraciones largas y complejas. Este estilo es consecuencia, en parte, de la reproducción de declaraciones de figuras públicas, como parlamentarios o magistrados, que usan un registro muy formal.

4. La sintaxis y el léxico periodístico están estandarizados para evitar impropiedades.

5. El estilo de la escritura debe ser compacto para ahorrar tiempo y espacio. A fin de contener la mayor información en el menor espacio, la densidad léxica, la ratio entre palabras y elementos léxicos, es muy alta, y se utilizan frecuentemente oraciones relativas y nominalizaciones.

Debemos entender la noticia como un modelo de texto autónomo dentro del periodismo informativo, ya que tiene unas singularidades que lo definen como tal. Es el género periodístico por excelencia, pues la información que transmite es el punto más importante de atracción para el lector. Pero además, es lo que antecede a todos los demás géneros, tanto de información como de opinión, pues incluso las entrevistas que no están originadas por la actualidad informativa, las llamadas de personalidad, también tienen su implicación en alguna noticia anterior en la que se da a conocer el personaje que ahora tiene relevancia social.

La noticia es la antesala de los géneros de opinión. Provoca las distintas interpretaciones de sus antecedentes y consecuencias, que son analizadas por periodistas en los artículos firmados, y por las empresas propietarias de los medios en los editoriales. Y lo mismo sucede con la crónica y la crítica de arte, que son textos interpretativos de hechos que han sido noticia, pues están necesariamente relacionados con la actualidad y la novedad.

Es un género que no debe contener la opinión del redactor. No es un texto con interpretación, aunque pueda tenerla de forma implícita, ya que el hecho mismo de informar de un suceso con un determinado tratamiento, es ya una valoración sobre su mayor o menor importancia. Pero la interpretación explícita, la que incorpora elementos de valoración subjetiva, no tiene cabida en este género periodístico. Ana Francisca Aldunate y María José Lecaros consideran que en la noticia hay interpretación porque se da a conocer hechos, opiniones de protago-

74 El texto es un resumen que aparece en la Tesis Doctoral inédita Estudio de la cohesión léxica en la prensa británica. Ana Díaz Galán. Universidad de La Laguna, 2001. Volumen I, páginas 147, 148 y 149, que procede de La noticia como discurso, de van Dijk, Op. cit. 
nistas y posibles consecuencias, y se da a conocer procesos que han dado lugar a la actual información ${ }^{75}$, aunque estos datos realmente son una contextualización de los hechos y no una verdadera interpretación sobre su trascendencia.

$\mathrm{Su}$ texto debe limitarse a los criterios de estilo del periodismo informativo ya estudiado, donde la brevedad, la claridad y la exactitud son sus características fundamentales. Y, pese a que en la actualidad comienza a discutirse su idoneidad, la estructura de pirámide invertida es la que más se adecua a este género. Desde la titulación, el lead, y el cuerpo, el interés informativo va en orden decreciente a su importancia.

Con estas notas características, podemos definir la noticia como género periodístico de la siguiente forma: es un texto que trata sobre asuntos de la actualidad informativa de interés general, con el fin de informar de forma objetiva, y cuyo texto se caracteriza por la claridad, sencillez y exactitud.

\subsection{Estructura}

La noticia es un género con una estructura formal que también la distingue como género autónomo. Víctor Rodríguez ofrece la más sencilla, en la que distingue dos partes ${ }^{76}$ : el encabezamiento y el cuerpo. La primera, compuesta por los titulares y el lead, debe contener el resumen total de toda la información, por lo que tiene que responder a las cinco, o seis, W. De acuerdo con este modelo se manifiesta Fernando García Núñez, quien considera que la información, que es como denomina a este género, sólo consta de dos partes: el lead o entradilla, que considera el alma de la noticia, y que debe contestar a las seis preguntas clásicas; y el cuerpo o desarrollo, que incluye una exposición detallada del suceso con el resto de datos no ofrecidos en la primera parte ${ }^{77}$.

Los detalles del acontecimiento que es objeto de la información suelen ir en orden decreciente al de la importancia de los mismos. Es el denominado diagrama de la pirámide invertida, en el que los detalles más notables e importantes van al principio, y el resto del contenido se redacta de forma descendente a su interés. Un esquema que es defendido por autores como Guillermina Baena $\mathrm{Paz}^{78}$, o María Pilar Diezhandino, quien señala cuatro ventajas desde el punto de vista práctico de la estructura de la pirámide invertida, basadas en los estudios de MacDougall ${ }^{79}$ :

1. Facilita la lectura.

2. Satisface la curiosidad.

3. Facilita la composición.

4. Facilita escribir el titular.

75 Vid. Géneros Periodísticos. Op. cit. página 34.

76 Vid. Manual de redacción. Op. cit. página 157.

77 Vid. Cómo escribir para la prensa. Op. cit. página 43.

78 Vid. Géneros periodísticos informativos. Op. cit. página 99.

79 Vid. El quehacer informativo. Op. cit. página 97. 
Sin embargo, en la actualidad se ha puesto en duda por parte de algunos autores al entender que debido a la inmediatez con la que trabajan los medios audiovisuales, los lectores ya conocen la información, y los periódicos se convierten cada día más en recursos que ofrecen un papel interpretativo de las noticias. La pirámide invertida comienza a dejar de ser una estructura aceptada por todos. Álex Grijelmo opina que ha quedado obsoleta, ya que tuvo su razón de ser cuando los periódicos se componían en plomo y siempre era posible la eliminación de una parte del texto en el momento de la maquetación. Es una época en la que no podía preverse con exactitud el espacio que podría dedicarse a un determinado escrito, por lo que el periodista dejaba para el final lo menos importante, que era lo que posiblemente se le quitaría en caso de necesidad. Hoy, con la informatización, se sabe exactamente el espacio con el que se cuenta para una información o un artículo, por lo que se tiene la seguridad de que no se va a suprimir parte del trabajo, y, cuando excepcionalmente hay que recortar un texto, puede reelaborarse en el ordenador y quitar lo menos interesante, que no necesariamente está al final del trabajo ${ }^{80}$. Además, algunos autores proponen estructuras alternativas para los géneros informativos. Ana Francisca Aldunate y María José Lecaros plantean la pirámide de citas, en la que se comienza por una que sea atractiva para el lector; o la pirámide cronológica, donde prima la secuencia temporal sobre la importancia de los ítems informativos ${ }^{81}$.

Núñez Ladevéze propone un modelo de estructura para la noticia con tres partes claramente diferenciadas ${ }^{82}$ : el título, el párrafo de entrada, y el texto informativo. Equivale a la ya comentada de Víctor Rodríguez, aunque separa dentro del encabezamiento las dos partes que lo componen: el título y el lead, y aclara que entre los diferentes componentes del texto debe existir una coherencia temática, aunque cada párrafo debe constituir una unidad segregable de las demás sin que peligre su gramaticalidad interna ${ }^{83}$. Un modelo similar propone Luis Alberto Hernando Cuadrado, para quien la noticia tiene también tres partes con los mismos contenidos, aunque con una terminología diferente ${ }^{84}$ : el titular, que puede contener título, subtítulo y antetítulo; la entrada, o lead, que contiene lo esencial de la noticia; y el cuerpo, que desarrolla y completa la información.

En una noticia es necesario identificar en primer lugar la macroestructura semántica, o asunto del que trata. A continuación debemos distinguir las proposiciones informativas que contiene el texto, que deberán estar ordenadas por la importancia de las mismas, si responden al esquema de la pirámide invertida, y

80 Vid. El estilo del periodista. Op. cit. páginas 32 y 33.

81 Vid. Géneros Periodísticos. Op. cit. página 24.

82 Vid. Introducción al periodismo escrito. Op. cit. página 46.

83 Ibídem, página 77.

84 Vid. El discurso periodístico. Op. cit. página 17. 
que están funcionalmente relacionadas con la macroestructura para lograr la coherencia necesaria ${ }^{85}$. Fernando Martínez Vallvey hace una clasificación de los párrafos que integran una noticia, a modo de una estructura compuesta por seis partes: entradilla, datos principales, datos secundarios, de citas, párrafo de cuello y datos explicativos ${ }^{86}$.

Pero en la noticia, realmente se distinguen tres partes con unas funciones específicas perfectamente identificables: la titulación, el lead y el cuerpo. La titulación, que puede estar formada por antetítulo, título y subtítulo, resume lo más importante del contenido de la información. En el título se debe concentrar en pocas palabras el núcleo principal de la noticia, con una redacción que atraiga la atención del lector. El lead, también separado del cuerpo y con una tipografía diferenciada, debe complementar la titulación con la esencia de lo sucedido, una función que puede ejercerla el primer párrafo del texto en caso de ausencia de aquél. En el cuerpo se pueden distinguir varios componentes -el hecho principal, los comentarios y los antecedentes-, aunque es difícil determinarlos con carácter general, pues no siempre aparecen. En esta parte, lo más destacable es su estructura de pirámide invertida, ya que, al margen del debate que ello suscita, el lector prefiere encontrar lo más importante al comienzo del texto, pues no siempre concluye su lectura.

\subsubsection{La titulación}

El primer elemento de la noticia está dirigido a atraer la atención del lector. Para Van Dijk, la titulación, que denomina resumen, está compuesto por el titular, el antetítulo, uno o varios subtítulos, y la entradilla, o $l_{e a d}{ }^{87}$, mientras que José R. Vilamor afirma que el resumen, o encabezamiento, está compuesto por el titular y la entradilla, y deben bastar al lector para darse por enterado de manera concisa de lo esencial de la información ${ }^{88}$.

Es necesario destacar que la noticia está encabezada principalmente por el título, que debe contener lo más importante de la información, y constituir el principal punto de atracción hacia la lectura del texto. Para Álex Grijelmo, cuanto más breve es el titular, mejor es la noticia ${ }^{89}$, por lo que siempre deberá elaborarse con tres condiciones indispensables: ha de ser claro, breve y atractivo ${ }^{90}$. El titular, en ocasiones, está acompañado de un antetítulo, que puede situar geográfica o ambientalmente la noticia, y de un subtítulo que puede complementar la información y la captación del lector. Josep Lluis Gómez Mompart considera que, además

85 Vid. Teun A. Van Dijk: La noticia como discurso. Op. cit. página 99.

86 Vid. Cómo se escriben las noticias. Librería Cervantes, Salamanca, 1999, página 60.

87 Vid. La noticia como discurso. Op. cit. página 83.

88 Vid. Redacción periodística para la generación digital. Op. cit. página 182.

89 Vid. El estilo del periodista. Op. cit. página 46.

90 Ibídem, página 456. 
del título, el subtítulo y el antetítulo, son también partes de la titulación los ladillos, o intertítulos, que se insertan en el texto para aligerar su lectura, y la catenaccio, que sirve para hacer resaltar una información que no está contenida en la titulación, pero que aparece dentro del texto ${ }^{91}$.

Martínez Albertos y Luisa Santamaría resaltan la importancia del título como elemento destinado a atraer lectores, y lo definen como el párrafo inicial del encabezamiento destinado a llamar la atención sobre una información o sobre un conjunto de textos periodísticos ${ }^{92}$. Además, determinan las tres funciones periodísticas que a su juicio corresponden a los títulos: identificar los textos que encabezan, distinguir los géneros entre sí, y despertar el interés de los lectores ${ }^{93}$. Los titulares son, para Martínez Vallvey, el conjunto de elementos que en un texto periodístico indican cuál es el contenido e importancia del escrito informativo ${ }^{94}$.

El título es una parte esencial de la noticia, y su tipografía diferenciada con respecto al cuerpo de la información pretende captar el interés de los receptores. Juan Gutiérrez Palacio afirma que la titulación en la noticia tiene tal importancia que puede llegar a ser considerada como una parte de la interpretación ${ }^{95}$. Para lograr atraer al lector se redacta con unas características gramaticales muy particulares, como el hecho de omitir formas verbales, o utilizarlas en presente, en lugar del uso de participios.

Luis Alberto Hernando Cuadrado propone una clasificación de titulares muy sencilla $\mathrm{a}^{96}$ : indicativos y explicativos, aunque es Karl Bühler ${ }^{97}$ quien propone la que posiblemente es la más aceptada hasta el momento: titulares informativos, apelativos y expresivos. Los primeros tienen como función principal identificar los datos de la unidad a que se refiere el texto informativo, y son los más comunes. El titular apelativo posee gran impacto, y es el más utilizado en la prensa sensacionalista, ya que se dirige al lector para movilizarlo en favor de una determinada opinión de forma persuasiva. En este caso, se hace referencia a la macroestructura semántica, pero no se refleja lo más importante de la información. El titular expresivo es muy breve y está elaborado con gran fuerza, ya que intenta reproducir los sentimientos que la noticia va a suscitar en los lectores.

José Javier Muñoz cree que toda titulación debe $\operatorname{ser}^{98}$ : adecuada, sugestiva, concisa, directa, informativa y proporcionada a la importancia de la noticia, mientras que Josep Lluis Gómez Mompart considera que debe cumplir con cinco

91 Vid. Los titulares en Prensa. Op. cit. páginas 28 y 29.

92 Vid. Manual de estilo. Op. cit. página 148.

93 Ibídem.

94 Vid. Herramientas periodísticas. Op. cit. página 88.

95 Vid. Periodismo de opinión. Paraninfo, Madrid, 1984, página 54.

96 Vid. El discurso periodístico. Op. cit. página 23.

97 Cfr. Núñez Ladevéze, Luis: Introducción al periodismo escrito. Op. cit. página 62.

98 Vid. Redacción periodística. Op. cit. páginas 181 y 182. 
criterios fundamentales: actualidad, concisión, claridad, veracidad y garra ${ }^{99}$. Para Vilamor, el titular es una especie de escaparate que sirve de reclamo para que el lector se anime y entre dentro del establecimiento, es decir, lea la información completa $^{100}$.

La titulación en la noticia se diferencia de la de otros textos periodísticos. Núñez Ladevéze considera que en este género debe ser un resumen informativo, mientras que en los géneros del periodismo de opinión son más expresivos y estéticos ${ }^{101}$. Gonzalo Martín Vivaldi coincide con este planteamiento en la titulación de los géneros informativos, donde estima que no se deben superar las once o doce palabras, mientras que en los géneros de opinión hay plena libertad, y su autor tiene como único límite hacerlo sugestivo ${ }^{102}$. Para Josep Lluis Gómez Mompart, la titulación de la noticia tiene una función informativa que obliga a resumir lo más destacado de la información, pero posee una segunda función no menos importante, que es la de atracción a los lectores ${ }^{103}$.

Si analizamos la titulación de las noticias que nos ofrecen los periódicos, podemos llegar a la conclusión de que se diferencian principalmente por dos criterios: su composición gráfica, y su mayor o menor grado informativo. No es igual la que tiene solamente un título, que la formada, además, por un antetítulo -que puede situar la información en un determinado contexto-, y un subtítulo -que facilita complementar lo esencial de la noticia-. Pero también se distinguen por su contenido, pues hay titulaciones que informan plenamente con un solo título, y otras que, pese a tener antetítulo o subtítulo, no lo hacen de forma efectiva. Por ello, podríamos clasificar las titulaciones de la noticia en los siguientes tipos:

1. Por su composición:

1.1. Simple: si está formada solamente por un título.

1.2. Compuesta: si contiene, además del título, algún otro componente (antetítulo o subtítulo).

2. Por su grado de información:

2.1. Informativa: si condensa lo esencial de la noticia.

2.2. Apelativa: cuando menciona el asunto del que trata, pero no dice exactamente lo que ha sucedido.

2.3. De impacto: la que no ofrece ningún dato de la información, y contiene, en pocas palabras, un mensaje llamativo.

99 Vid. Los titulares en Prensa. Op. cit. página 34.

100 Vid. Redacción periodística para la generación digital. Op. cit. página 186.

101 Vid. Introducción al periodismo escrito. Op. cit. página 37.

102 Vid. Curso de Redacción. Op. cit. página 334.

103 Vid. Los titulares en Prensa. Op. cit. página 10. 


\subsubsection{El lead}

El lead, la entradilla, o el párrafo de entrada, es, después del título, el segundo punto de enganche de la noticia, para lo que se destaca tipográficamente con un tamaño menor que el titular pero mayor que el resto del texto. Si el título atrae, el lead debe confirmar el interés, por lo que es aquí donde deben estar resumidos los hechos de mayor relevancia, y expresar una o varias macroproposiciones temáticas del cuerpo informativo. Debe contener la mayor cantidad de información utilizando el menor número posible de palabras. En ocasiones se resume lo importante, pero se dejan conscientemente algunas incógnitas con el propósito de obligar al lector a leer todo el texto. La entradilla debe incluir lo que Van Dijk denomina "información pragmática acerca del hecho principal", es decir, contestar, en lo posible, a las "cinco W" (who, what, when, where, why), con el orden gramatical apropiado: sujeto, verbo y complementos ${ }^{104}$. En contra de esta opinión se muestra Álex Grijelmo, quien afirma que la entradilla no tiene que responder a estas interrogantes, y pueden ir desgranadas a lo largo del texto ${ }^{105}$.

Mientras algunos autores hablan indistintamente de lead o entradilla, Martínez Aguinagalde sostiene que no son lo mismo, ya que, mientras el primero es conciso y atrae en pocas palabras al lector con una tipografía diferenciada, la entradilla, o primer párrafo del cuerpo de la noticia, condensa lo más importante dentro de la información y complementa la titulación ${ }^{106}$, por lo que cumple la función informativa del lead cuando éste falta.

La raíz etimológica de lead es la misma que líder, y nos indica qué es lo que va al principio de la noticia ${ }^{107}$. Si el primer párrafo tiene mucha importancia en cualquier género periodístico, en la noticia es aún mayor, ya que debe incluir las proposiciones esenciales del contenido informativo, y decir al lector qué es lo que va a encontrar en el texto. Por tanto, la entradilla debe relatar de forma clara y con exactitud lo más importante de lo que ha sucedido y el tono general de lo relatado. Sin embargo, debe ser breve, y nunca superar las treinta o treinta y cinco palabras. Pero, aunque es un resumen, no debe tener el estilo telegráfico propio del título.

Para el profesor Martínez Albertos, el lead -que en su opinión debe traducirse al castellano por "arranque", "entrada" o "comienzo"- de la noticia es diferente al de los demás textos periodísticos ${ }^{108}$. En cualquier trabajo publicado en prensa, el párrafo inicial es muy importante, pero mientras en todos los géneros

\footnotetext{
104 Vid. Martínez Albertos, José Luis y Luisa Santamaría Suárez: Manual de estilo. Op. cit., página 115. 105 Vid. El estilo del periodista. Op. cit., página 34.

106 Vid. El uso de la entradilla en los textos periodísticos informativos e interpretativos. Editorial Fragua, Madrid, 1997, página 16.

107 Vid. González Rodríguez, María J.: Análisis sociolingüístico-textual del lead en los diarios nacionales británicos. Tesis Doctoral inédita. Universidad de La Laguna, 1999, página 123 y siguientes.

108 Vid. Redacción periodística. Editorial ATE, Barcelona, 1974, página 91.
} 
periodísticos el único objetivo es atraer la atención de los lectores, en la noticia, sin olvidar éste, su función principal es la informativa. Para Núñez Ladevéze, la entradilla es la parte principal del texto de la noticia, que luego ha de ser complementada con detalles informativos en el cuerpo de la misma ${ }^{109}$.

El lead, o entradilla, tiene que ser riguroso, claro, preciso y exacto. Debe evitar el sensacionalismo y la espectacularidad fácil, y su redacción está en función de los intereses de los lectores de un determinado periódico. De esta forma cumplirá la función de atraer al receptor, como complemento de los titulares.

\subsubsection{El cuerpo}

El desarrollo del texto informativo es denominado episodio por Teun A. van Dijk, que considera, junto al comentario, la parte más importante de la información, pues relata en todos sus detalles cada uno de los hechos integrantes de la noticia anunciados en el resumen o encabezamiento ${ }^{110}$. El episodio está compuesto de tres partes: el contexto (las circunstancias sociales y culturales del momento en que se produce el hecho noticiable), los antecedentes (los datos del pasado que pudieran estar relacionados con la información), y la historia (los hechos del pasado que han podido originar de forma directa o indirecta lo que ahora es noticia). En ocasiones, las distintas partes del episodio son difíciles de distinguir entre ellas, al expresarse de forma conjunta. Martínez Albertos y Luisa Santamaría prefieren denominarlo cuerpo, que abarca el grueso de la información con la estructura de la conocida pirámide invertida ${ }^{111}$, por lo que deberá contener una exposición ordenada de los datos que se ofrecen.

Las consecuencias aparecen, o pueden aparecer, a continuación del episodio. Son los efectos que se originan a raíz de lo informado, así como la trascendencia del suceso. La última parte está formada por los comentarios, que son las reacciones verbales que la noticia provoca. El orden en el que aparecen estas partes puede cambiar en función de la importancia de cada una de ellas dentro de la información. En ocasiones, los comentarios son de tal relevancia que no van al final de la noticia, sino que pueden aparecer en la entradilla, e incluso en los titulares. Por ello, la ordenación de las proposiciones informativas está en función no sólo de la estructura temática de cada una de ellas, sino también hay que tener en cuenta la relevance structure, es decir, la importancia de cada ítem informativo dentro de la noticia.

Para Daniel Jorques, las propiedades que definen la textualidad nacen en la gestación interna del mensaje informativo: adecuación, coherencia y cohesión ${ }^{112}$.

109 Vid. Introducción al periodismo escrito. Op. cit., página 70.

110 Vid. La noticia como discurso. Op. cit., página 84.

111 Vid. Manual de estilo. Op. cit., página 117.

112 Vid. Discurso e información. Estructura de la prensa escrita. Servicio de Publicaciones de la Universidad de Cádiz, 2000, página 17. 
La adecuación es la adaptación del texto al contexto comunicativo, la coherencia es la propiedad por la que el texto se interpreta como una construcción de unidades, y la cohesión es la que establece relaciones entre las distintas unidades del trabajo. Este autor considera que el texto de una noticia se conforma como un agrupamiento de codificaciones (la tarea del periodista), comprensiones (la labor decodificante del lector), y percepciones (la estructura del titular como impacto inicial de la noticia). Así, el texto es una unidad psíquica formada por datos para representar conceptos almacenados en la memoria de los lectores ${ }^{113}$.

En el cuerpo de la noticia, normalmente, hay tres componentes perfectamente diferenciables: el hecho principal, los comentarios y los antecedentes. Aunque no todos los medios informativos utilizan la pirámide invertida, el hecho principal de la información suele estar al comienzo del cuerpo, al que le siguen los comentarios -reacciones verbales de los protagonistas directos, personas relacionadas con los hechos, o expertos cuya opinión ayuda al lector a entender lo sucedido-; y los antecedentes -que no tienen ubicación fija, y que en algunas ocasiones aparecen en los titulares-.

\subsection{Tipología}

Fernando Martínez Vallvey hace una pormenorizada clasificación de las noticias según diferentes puntos de vista ${ }^{114}$ :

1. En función de cómo se conoce la noticia: fortuitas, previsibles y programadas.

2. Según su contenido: de interés humano y de interés sustantivo.

3. Por la identidad de las fuentes: oficiales, oficiosas y extraoficiales.

4. Según la proximidad de la fuente: de un nivel o de varios niveles.

5. En función de los asuntos que tratan: simples o múltiples.

6. Por su función informativa: directas y de creación.

7. Según su estructura redaccional: cronológicas, citas, de pirámide invertida y guías.

8. Por su extensión: cuñas, breves, fotonoticias, noticias habituales, y noticias reportajeadas.

Luis Núñez Ladevéze estima que se pueden distinguir tres clases de noticias según la importancia que tienen para los periodistas ${ }^{115}$ :

1. Noticias de información común, que son las menos importantes, y de las que disponen todos los medios. 
2. Noticias de información exclusiva, que son las conseguidas por un sólo medio informativo, por lo que tienen gran importancia periodística, no por el asunto del que trata sino porque ningún otro medio la conoce.

3. Noticias de información temática, que son las relativas a determinados asuntos que para el medio informativo en particular son de especial trascendencia.

Para Guillermina Baena Paz, las noticias se deben clasificar por su contenido, y distingue las políticas, económicas, agropecuarias, científicas, educativas, deportivas, culturales, artísticas, policíacas, sociales y de interés humano ${ }^{116}$.

Pero además de su contenido, es necesario distinguirlas por su ámbito, de manera que las informaciones políticas del Ayuntamiento de un pueblo de Castilla no deben ser contempladas en el mismo grupo que una noticia sobre las últimas decisiones de la Unión Europea en cuanto a la incorporación de nuevos países. Por tanto, es necesario hacer una doble clasificación, según ambos aspectos:

1. Por su ámbito: locales, nacionales e internacionales.

2. Por su contenido: políticas, económicas, deportivas y sociales.

\section{La entrevista}

El diálogo entre un periodista y el entrevistado puede tener tres objetivos: obtener alguna información sobre un hecho presencial, conocer sus comentarios sobre algo sucedido, o hacer una semblanza del personaje. En este apartado nos referiremos a las dos últimas acepciones, $\mathrm{y}$, concretamente, las publicadas en un medio informativo escrito. La entrevista, como género periodístico, la entendemos como el texto resultante de esta conversación, que puede estar redactado en primera persona -con las palabras textuales de ambos-, o como un artículo basado en las declaraciones de un determinado personaje, es decir, una entrevista creativa.

Antonio López Hidalgo considera que la entrevista es un género auxiliar de otros, como la crónica o el reportaje ${ }^{117}$, y Gabriel García Márquez opina que la entrevista es el "género maestro", porque en ella está la fuente de la cual se nutren todos los géneros periodísticos ${ }^{118}$. Montserrat Quesada la define como un método mediante el cual un periodista entra en contacto con un personaje que despierta interés público por su personalidad o el cargo que ocupa ${ }^{119}$, aunque diez años más tarde, esta autora, en una obra conjunta con Eric Frattini, le añade un condicionante a esta definición que le otorga mayor exactitud, al concretar que se trata de un "texto especializado"120.

116 Vid. Géneros periodísticos informativos. Op. cit., páginas 99 y 100.

117 Vid. La entrevista periodística. Entre la información y la creatividad. Op. cit., página 73.

118 Vid. "Sofismas de distracción". Sala de prensa. Web para profesionales de la comunicación iberoamericanos, marzo, 2001, página 2.

119 Vid. La entrevista: obra creativa. Mitre, Barcelona, 1984, página 119.

120 Vid. La entrevista. El arte y la ciencia. Eudema, Madrid, 1994, página 232. 
Para Fernando Martínez Vallvey es el género más auténticamente periodístico, aunque también considera que es el que menos se ha estudiado, y parece ser la hermana pobre de las Ciencias de la Información ${ }^{121}$. Todo lo contrario opina Antonio López Hidalgo, quien afirma que es el género que más se ha investigado y uno de los que más monografías han originado ${ }^{122}$.

Aunque, como dice Waldrop ${ }^{123}$ las definiciones "suelen ser aburridas además de incompletas", vamos a analizar lo que de este género han dicho varios estudiosos. Manuel del $\mathrm{Arco}^{124}$ nos ofrece la definición más breve, y que puede servirnos para iniciar su estudio: es una conversación llevada a letra impresa. La entrevista es un género periodístico eminentemente informativo, aunque puede incluir alguna apreciación del periodista en forma de comentario de forma explícita sobre el contexto, pero nunca sobre sus respuestas, ya que su fin es informar objetivamente de las opiniones expresadas por el entrevistado. Sin embargo, Antonio López Hidalgo, de acuerdo con Fernando Martínez Vallvey, considera que la entrevista tiene una función persuasiva, porque las opiniones del entrevistado son ya una subjetividad, por lo que estima que puede ser catalogado como un género periodístico de opinión ${ }^{125}$, aunque el mismo autor aclara a continuación que la subjetividad de estas opiniones está ligada a la persona, y no al periodista ni al texto que finalmente se publica. Ana Francisca Aldunate y María José Lecaros afirman que una entrevista es, sencillamente, un intercambio oral o escrito sobre un tema con una persona de relevancia que despierta interés en la opinión públi$\mathrm{ca}^{126}$. La mayoría de las definiciones insisten en dos elementos ineludibles: el diálogo y el antagonismo de los que hablan ${ }^{127}$.

Núñez Ladevéze profundiza un poco más al considerar que la entrevista es un género principalmente informativo, aunque también existen distintas modalidades de ésta que no lo son estrictamente ${ }^{128}$, mientras que Víctor Rodríguez afirma que es un subgénero dentro del reportaje cuando el texto se redacta en tercera persona y no reproduce literalmente las palabras del entrevistado. Para este autor, la entrevista es una forma de reportaje que se le supone de máximo interés porque nos sitúa en contacto directo con el mundo particular y privado de unas personas que destacan por sus cualidades intelectuales, artísticas, humanas, o el cargo que

121 Vid. La entrevista periodística desde el punto de vista conversacional. Publicaciones Universidad Pontificia, Salamanca, 1995, página 57.

122 Vid. La entrevista periodística. Entre la información y la creatividad. Op. cit., página 14.

123 Cfr. Abril Vargas, Natividad: Periodismo de opinión. Op. cit., página 143.

124 Cfr. Balsebre, Armand y otros: La entrevista en radio, televisión y prensa. Editorial Cátedra, Madrid, 1998, página 246.

125 Vid. La entrevista periodística. Entre la información y la creatividad. Op. cit., página 82.

126 Vid. Géneros Periodísticos. Op. cit., página 37.

127 Vid. Rodríguez Betancourt, Miriam: La entrevista periodística y su dimensión literaria. Tauro Ediciones, Madrid, 2001, página 18.

128 Vid. Introducción al periodismo escrito. Op. cit., página 89. 
ostentan $^{129}$. Juan Gutiérrez Palacio ${ }^{130}$ y María Pilar Diezhandino ${ }^{131}$ consideran también que la entrevista es una modalidad particular del reportaje objetivo, mientras que Montserrat Quesada afirma que la entrevista es un género autónomo perfectamente diferenciado del reportaje por sus particularidades estilísticas y su estructura formal.

El profesor Martínez Albertos considera que la entrevista es un subgénero dentro de los géneros periodísticos informativos, y afirma que es muy corriente en los periódicos sensacionalistas por el sentimiento de proximidad que da al lector. Este autor asegura que si aceptamos que hay dos modelos de periodismo -el anglosajón y el latino-, es en este último donde más se utiliza la entrevista como medio sensacionalista ${ }^{132}$, afirmación con la que Antonio López Hidalgo discrepa, y califica de "falsa realidad", pues si bien es verdad que en el periodismo no riguroso abundan las entrevistas, también es cierto que el sensacionalismo es un invento anglosajón. Además, afirma que la entrevista que más gusta en el periodismo latino es la creativa ${ }^{133}$.

José R. Vilamor ofrece una definición extensa en la que incluye los distintos tipos de este género periodístico ${ }^{134}$. En su opinión, la entrevista es la consecuencia del diálogo entre un periodista y un personaje, el resultado de una conversación formal con una persona a la que se acude para que dé su opinión autorizada sobre un hecho noticioso o para conocer distintos aspectos de su personalidad, e incluso para que comunique alguna novedad que puede originar una noticia. Héctor Borrat contempla la entrevista también como una conversación, aunque considera que realmente es el relato resultante de ella. Se trata de un texto que se publica en un periódico en el que se da cuenta del diálogo sostenido entre un periodista y otra persona de la que interesa su opinión sobre algún asunto ${ }^{135}$. José Julio Perlado también destaca en la entrevista el diálogo entendido como una apertura del entrevistado hacia el lector. De esta forma, el periodista sería el puente de relación entre las opiniones del personaje y las inquietudes culturales del receptor ${ }^{136}$.

Martínez Vallvey incorpora en su definición el concepto de ser un género periodístico diferenciado ${ }^{137}$. Para este autor, la entrevista es un tipo de texto en el que se refleja un diálogo entre dos personas, una de las cuales, el periodista, plantea sus intervenciones en un nivel distinto al entrevistado, ya que procura

129 Vid. Manual de redacción. Op. cit., página 160.

130 Vid. Periodismo de opinión. Op. cit., página 107.

$131 \mathrm{Vid}$. El quehacer informativo. Op. cit., página 86.

132 Vid. Curso General de redacción periodística. Op. cit., página 323.

133 Vid. La entrevista periodística. Entre la información y la creatividad. Op. cit., páginas 71 y 72.

134 Vid. Redacción periodística para la generación digital. Op. cit., página 358.

135 Vid. El periódico, actor político. Editorial Gustavo Gili, Barcelona, 1989, página 128.

136 Vid. Diálogos con la cultura. La entrevista periodística. Ediciones Internacionales Universitarias, Barcelona, 1995, página 19.

137 Vid. Cómo se escriben las noticias. Op. cit., página 77. 
motivarle para que hable en una determinada dirección. Karl Warren ${ }^{138}$ también habla de texto con características propias, y la define como un artículo especializado basado en un diálogo con una persona cuyo nombre, actividad u opinión interesa a los demás.

Leonor Arfuch opina que la entrevista es, ante todo, una narración, porque nos acerca a los personajes entrevistados a través de sus opiniones personales ${ }^{139}$, y en la misma línea se manifiesta David Vidal, quien basado en los estudios del teórico ruso Mijail Batjin, prefiere definir la entrevista no como un género específicamente periodístico, sino como un texto discursivo debido a que es una comunicación oral, es decir, enunciativa ${ }^{140}$.

José Javier Muñoz plantea cuatro condiciones que debe cumplir toda entrevista: interés real por su protagonista o por la calidad de sus respuestas, primera condición sin la cual no merece ser publicada; justeza en la transcripción, pues, aunque no se publique lo contestado literalmente, tiene que reflejar la intención de cada respuesta; naturalidad en lo escrito, que debe transmitir al lector el tono en el que se desarrolló la conversación; y amenidad, que son las aportaciones del periodista en la descripción del ambiente para lograr un texto agradable ${ }^{141}$. Y Martínez Vallvey señala otras cuatro características fundamentales que considera definitorias de este género periodístico ${ }^{142}$. En primer lugar es un tipo de texto difundido en cualquier medio de comunicación en el que se refleja la verdad del contenido de una conversación. La segunda condición es que este diálogo ha tenido que ser necesariamente planificado y programado. También, debe reflejarse el texto con la máxima claridad para que sea entendido por el receptor. Por último, la entrevista tiene el doble objetivo de informar y de formar culturalmente a la población.

Podemos concluir que la entrevista es un género del periodismo informativo que refleja las respuestas de un personaje, cuyas opiniones, debido a su relevancia social, al cargo que ocupa, o a su implicación en hechos de la actualidad informativa, son de interés general. Por todo ello, las características esenciales podrían resumirse en cuatro puntos ${ }^{143}$ :

1. La entrevista es un género autónomo dentro del periodismo informativo.

2. Su texto refleja una conversación basada en preguntas y respuestas para conocer las opiniones de un personaje.

138 Cfr. Baena Paz, Guillermina: Géneros periodísticos informativos. Op. cit., página 123. 139 Vid. La entrevista, una invención dialógica. Ediciones Paidos, Barcelona, 1995, página 89.

140 Vid. Balsebre, Armand y otros: La entrevista en radio, televisión y prensa. Op. cit., página 263.

141 Vid. Redacción periodística. Op. cit., páginas 140 y 141.

142 Vid. La entrevista periodística desde el punto de vista conversacional. Op. cit., página 56.

143 Vid. Martínez Vallvey, Fernando: La entrevista periodística desde el punto de vista conversacional. Op. cit., página 61 . 
3. Puede reproducir las palabras del periodista y del entrevistado en primera persona, o integrar las respuestas obtenidas entre comillas dentro de un texto creativo.

4. Su objetivo es obtener información de hechos y de opiniones que interesan al lector.

\subsection{Algunas notas para su realización}

José Francisco Sánchez afirma que en una entrevista coinciden cuatro integrantes: el entrevistador, el entrevistado, el asunto y el contexto. De ellos, sólo uno permanece en el tiempo, mientras los otros cambian. Sólo el periodista continúa a través de las entrevistas de su vida ${ }^{144}$. Es necesario señalar que también existen otros elementos, como el medio de comunicación para el que se hace, con sus especificidades, y el público al que está dirigido, especializado o no. En el presente apartado trataremos de la entrevista en prensa no especializada.

La entrevista tiene tres momentos: la preparación del trabajo, la entrevista propiamente dicha, y la transcripción del texto. El primero es muy importante, y aunque en el periodismo se trabaja normalmente con urgencia, una buena preparación con datos sobre el personaje es imprescindible. Ésta es la fase en la que se determina si va a tener éxito el trabajo ${ }^{145}$. Disponer de abundante documentación, y hablar con personas próximas al entrevistado puede ser el secreto para un buen resultado. Con este material se confecciona un cuestionario, que será una herramienta útil, aunque no debe ser considerado como un documento fijo, ya que durante la conversación pueden surgir nuevos asuntos de interés que no estaban previstos.

En general, las preguntas que se hacen en una entrevista pueden ser clasificadas en abiertas y cerradas. Antonio López Hidalgo distingue, además, las extensas y las monosilábicas; y las generales y concretas $^{146}$. Las abiertas son aquéllas en las que el entrevistado tiene la posibilidad de responder como considere oportuno, mientras que las preguntas cerradas sólo admiten un monosílabo, aunque puede estar acompañado por una explicación. Guillermina Baena Paz distingue también las abiertas, con la definición anterior; las cerradas, que son aquéllas que ofrecen varias posibilidades de respuesta entre las que debe elegir el entrevistado, y las literales, que son las que requieren una respuesta concreta ${ }^{147}$. Pero una clasificación de preguntas en cuanto al objetivo que persiguen dentro de la entrevista nos la aporta José Francisco Sánchez, quien considera que el éxito en ocasiones depende de cosas tan sencillas como el orden de las preguntas que se

\footnotetext{
144 Vid. La entrevista periodística: introducción práctica. Editorial EUNSA, Pamplona, 1993, página 16. 145 Vid. Sherwood, Hugh: La entrevista. Editorial ATE, Barcelona, 1976, página 47.

146 Vid. La entrevista periodística. Entre la información y la creatividad. Op. cit., página 15.

147 Vid. Géneros periodísticos informativos. Op. cit., página 148.
} 
plantean, y recomienda una secuenciación bien planificada para lograr un buen trabajo $^{148}$ :

En primer lugar, y para ganar la confianza del entrevistado, se hacen las preguntas cómodas, fáciles de contestar, que aportan un ambiente distendido, apropiado para una conversación amistosa. Son cuestiones gratas de recordar para el personaje cuyas respuestas no van a aparecer en el texto que se publica, pero son el comienzo adecuado para una charla íntima en la que se establece un clima apropiado que posibilita obtener algunas confidencias. Es una fase de aproximación entre las dos partes, con el único objetivo de establecer un clima cordial que facilite la conversación posterior.

A continuación se plantean las preguntas examen, que se hacen para comprobar la sinceridad del personaje, y, por tanto, el grado de fiabilidad de sus palabras. Las respuestas ya las conoce el periodista, pero se hacen para saber si existe una actitud a la defensiva por parte del entrevistado o no. Aquí, la imaginación del periodista es la pieza clave ${ }^{149}$.

Las preguntas ordinarias en orden creciente de dificultad van a continuación. Es la fase más importante de la entrevista. Por medio de preguntas auxiliares, se pretende llevar al entrevistado a las cuestiones más comprometedoras. Se trata de preguntar cosas que incluso pueden ya conocerse parcialmente, pero se hacen con el objetivo de obligar al personaje a manifestarse sobre algo que, si no es de esta forma, evadiría con facilidad. Es un procedimiento denominado por algunos periodistas como "la técnica del embudo", aunque no es una regla aceptada por todos.

Las preguntas de humo se utilizan a lo largo de la entrevista con el objetivo de ganar tiempo ante respuestas inesperadas. Son preguntas abiertas que plantean cuestiones poco importantes que no interesan al periodista, para que en ese intervalo pueda meditar sobre un nuevo replanteamiento de alguna circunstancia imprevista que aparece en la conversación, y repreguntar algún aspecto concreto.

Una vez terminada la entrevista formal, vienen las preguntas finales sin grabadora ni bloc de notas. En estos momentos, el entrevistado se relaja y puede hacer alguna manifestación importante que en el transcurso de la entrevista no había hecho por estar a la defensiva. Es una fase que en ocasiones se convierte en la más importante de la conversación, pues en ella pueden aparecer respuestas sorprendentes, aunque las limitaciones éticas deben estar presentes. Siempre debe respetarse el "off the record" previamente pactado. Nos referimos a respuestas que se producen en los instantes finales, pero dentro de la conversación, cuando el entrevistado puede hacernos una confesión que hasta ese momento no había hecho.

148 Vid. La entrevista periodística: introducción práctica. Op. cit., páginas 33 y 34. 149 Vid. Sherwood, Hugh: La entrevista. Op. cit., página 135. 
Finalmente llega el momento de redactar lo que se va a publicar, es decir, a todo lo grabado y anotado hay que darle forma. Para Núñez Ladevéze, la transcripción al papel de la entrevista puede hacerse de acuerdo a tres estilos ${ }^{150}$ : el directo, con la utilización de la primera persona, el indirecto, redactada en tercera persona, y el interpretativo, que se asemeja a un artículo en el que se incluyen las opiniones del entrevistado.

Julio del Río también señala un modelo de entrevista redactada en tercera persona, dentro de la que se introducen algunas palabras entrecomilladas de las respuestas del entrevistado, sin la pregunta directa que las motivó. Es la entrevista que denomina narrativo-descriptiva, también llamada de semblanza o de persona$\operatorname{lidad}^{151}$, y que se parece a un artículo, ya que la frontera entre ambos géneros periodísticos en este caso es difusa. Se centra en los aspectos biográficos y de personalidad del entrevistado a través de sus respuestas, y permite de forma más abierta el uso de recursos literarios, aunque siempre debe prevalecer la función informativa.

También pueden combinarse los dos modelos, el de pregunta-respuesta y el narrativo-descriptivo, con un extenso sumario en el que se incluyen las palabras de mayor relevancia del entrevistado, y al que se añade a continuación el texto completo de las preguntas y respuestas, aunque no debe confundirse con la semblanza, en la que sólo se utiliza la tercera persona. David Vidal considera que hay que distinguir entre ambas, ya que la semblanza es un género de carácter biográfico que se centra en la personalidad del entrevistado, mientras que la entrevista con el modelo mixto antes explicado contiene algunas preguntas y respuestas en primera persona ${ }^{152}$.

\subsection{Estructura}

Aunque Antonio López Hidalgo opina que la estructura formal propia de este género es libre, especialmente en la entrevista creativa ${ }^{153}$, la mayoría de los autores que lo han estudiado coinciden en proponer un esquema muy similar. Susana González Reyna considera que la entrevista consta de tres partes: la entrada, que sirve para la presentación del personaje; el cuerpo, que contiene las preguntas y las respuestas; y la conclusión, que puede ser la última respuesta, un comentario del periodista o el final del relato ${ }^{154}$. Una estructura similar propone Guillermina Baena Paz ${ }^{155}$ : la entrada, que tiene como objetivo la atracción del

150 Vid. Introducción al periodismo escrito. Op. cit., página 94.

151 Vid. Teoría y práctica de los géneros periodísticos informativos. Op. cit., página 178.

152 Vid. Balsebre, Armand y otros: La entrevista en radio, televisión y prensa. Op. cit., página 301.

153 Vid. La entrevista periodística. Entre la información y la creatividad. Op. cit., página 105.

154 Vid. Géneros periodísticos 1. Periodismo de opinión y discurso. Op. cit., página 28.

155 Vid. Géneros periodísticos informativos. Op. cit., página 174 y siguientes. 
lector; el cuerpo, con las preguntas y respuestas; y el final, con una frase significativa o la reflexión personal del periodista. También en la misma línea se encuentra la propuesta de Montserrat Quesada ${ }^{156}$ : la entradilla, donde se presenta al personaje con una tipografía diferente al resto del texto; la introducción, en la que se describe al entrevistado y el ambiente que reina en la conversación; y la coletilla, que es donde el entrevistador puede añadir un gesto creativo al texto a modo de conclusión sin incorporar juicio de valor. Esta autora, diez años más tarde, en una obra conjunta con Eric Frattini, sustituye la coletilla por el cuerpo, que es la entrevista propiamente dicha ${ }^{157}$.

Son muchos los autores que proponen una estructura dividida en tres partes: la presentación, donde se esboza el perfil del personaje con un pequeño currículo personal, aunque cuando se trata de una persona muy conocida se puede sustituir por una descripción sobre el ambiente que existe en el diálogo; las preguntas y respuestas, que aparecen de forma directa y en primera persona, tal y como se produjo en la conversación; y por último, el final, que puede ser un comentario personal como conclusión del periodista. El modelo de José Francisco Sánchez, va en esta línea: entrada, cierre y comentarios marginales ${ }^{158}$; y lo mismo sucede con el que ofrece Martínez Vallvey: entradilla, introducción, cuerpo y cierre ${ }^{159}$. Para este autor, la entradilla es todo el encabezamiento de la entrevista, y su función también es atraer al lector, por lo que destacan sus mismos dos objetivos: el informativo y el estético. La introducción va a continuación, y es donde se presenta al entrevistado con un estilo muy creativo, y redactado en tercera persona. El cuerpo está formado por las preguntas y las respuestas, que se reflejarán en primera persona. Por último, la entrevista termina con el cierre, que nunca debe ser una frase del periodista, aunque en ocasiones es admisible un toque literario personal al final del texto.

La titulación, como en todo género periodístico, es importante para atraer la atención del lector, por lo que debe contener información acerca del contenido del texto. El modelo más corriente del título suele ser el nombre del entrevistado con una frase suya entrecomillada, y un subtítulo con otras declaraciones ${ }^{160}$, aunque David Vidal opina que la titulación depende del tipo de entrevista, pues cuando se trata de una informativa lo adecuado es una frase que a juicio del periodista sea lo más importante de las declaraciones, pero en la entrevista de personalidad es más aconsejable un titular apelativo en tercera persona ${ }^{161}$. En opinión de Martínez Aguinagalde, la entradilla, como complemento de la titulación, debe contener

156 Vid. La entrevista: obra creativa. Op. cit., página 33.

157 Vid. Frattini, Eric y Montse Quesada: La entrevista. El arte y la ciencia. Op. cit., página 312.

158 Vid. La entrevista periodística: introducción práctica. Op. cit., página 52.

159 Vid. La entrevista periodística desde el punto de vista conversacional. Op. cit., páginas 67 y 68.

160 Vid. Grijelmo, Alex: El estilo del periodista. Op. cit., página 470.

161 Vid. Balsebre, Armand y otros: La entrevista en radio, televisión y prensa. Op. cit., página 375. 
como mínimo tres datos del entrevistado: nombre, actividad habitual, y motivo concreto de la entrevista ${ }^{162}$.

Para Antonio López Hidalgo, el estilo de este género es libre, por lo que su función informativa no debe impedir un lenguaje creativo ${ }^{163}$, y José Julio Perlado afirma que el estilo en toda entrevista debe respetar un escrupuloso equilibrio entre la profundidad y la amenidad, es decir, debe tener calidad informativa sin olvidar la belleza expresiva ${ }^{164}$. Es un género del periodismo informativo, pero no tiene que contestar las cinco W, como en el caso de la noticia. Montserrat Quesada opina que en la entrevista se debe responder sólo a cuatro de ellas: quién es el entrevistado, qué es, cómo opina y dónde se realiza la entrevista ${ }^{165}$.

En la estructura de la entrevista informativa se pueden distinguir claramente tres partes, que los distintos autores denominan de forma diferente:

1. Presentación, que consta de titulación y entradilla, que junto a la fotografía y pie de foto nos muestran el personaje y el motivo de la entrevista. En el titular se refleja una frase importante de las contestaciones que recoge el texto, mientras que en la entradilla se ofrece un perfil del entrevistado, aunque cuando se trata de un personaje muy conocido se sustituye por un comienzo atractivo para el lector que explica el ambiente de la conversación.

2. Cuerpo, en el que se plasman las preguntas y respuestas en primera persona, con la mayor fidelidad posible a las palabras pronunciadas por el entrevistado -entrevista directa-, o está integrado por un texto más literario con algunas respuestas entrecomilladas del personaje -entrevista creativa-.

3. Final, o cierre, en el que se admite una frase final del periodista o una respuesta significativa del entrevistado.

\subsection{Tipología}

Sigfried Mendel ${ }^{166}$ afirma que "las entrevistas son tan variadas como las personas que las conceden, los reporteros que las hacen y las noticias que las suscitan", y Montserrat Quesada asegura que hay casi tantos tipos de entrevistas como periodistas entrevistadores ${ }^{167}$. Dejando al margen la posible exageración de ambas aseveraciones, son varios los autores que clasifican las entrevistas en dos grupos. Antonio López Hidalgo distingue las de declaraciones, que son de contenido fundamentalmente informativo; y las de creación, con aportaciones más literarias ${ }^{168}$, y David Vidal comparte esta idea con una propuesta casi coincidente:

\footnotetext{
$162 \mathrm{Vid}$. El uso de la entradilla en los textos periodísticos informativos e interpretativos. Op. cit., página 59. 163 Vid. La entrevista periodística. Entre la información y la creatividad. Op. cit., página 15.

164 Vid. Diálogos con la cultura. La entrevista periodística. Op. cit., página 56.

165 Vid. La entrevista: obra creativa. Op. cit., página 113.

166 Cfr. Aldunate, Ana Francisca y María José Lecaros: Géneros Periodísticos. Op. cit., página 37.

167 Vid. Frattini, Eric y Montse Quesada: La entrevista. El arte y la ciencia. Op. cit., página 234.

168 Vid. La entrevista periodística. Entre la información y la creatividad. Op. cit., página 75.
} 
la informativa/temática objetiva/de declaraciones, que es la relacionada con la actualidad; y la de personaje/literaria/creativa, que tiene un tinte más subjetivo ${ }^{169}$. Ésta segunda, que Montserrat Quesada denomina creativa o literaria, se centra en la personalidad del entrevistado y todo aquello que lo identifica, por lo que responde principalmente a "quién es" 170 .

Martínez Aguinagalde también distingue solamente dos tipos de entrevistas, que diferencia por los motivos que llevan al periodista a realizarla: por la actualidad de unos hechos de interés social, y por la personalidad del entrevistado, sin que ningún hecho noticiable se haya producido en su inmediatez ${ }^{171}$. Son clasificaciones similares aunque proponen una terminología diferente, ya que en todas se distingue un modelo que se centra en un personaje de forma objetiva, y otro en el que se aprecia un texto más creativo. Pero otros autores consideran que entre las entrevistas hay suficientes factores que pueden hacer diversificar más los tipos de entrevistas. Veamos algunos de ellos.

Martínez Albertos distingue tres modalidades ${ }^{172}$ : las declaraciones, que son aquellas en las que se reflejan las opiniones de un personaje sobre un asunto que tiene interés colectivo en ese momento; la entrevista de personalidad, que está motivada principalmente por la importancia de la persona entrevistada, y no por la oportunidad; y la entrevista con fórmulas ya establecidas, también llamada "cuestionario Marcel Proust", que es un modelo en el que el entrevistado contesta a un formulario de preguntas ya preparado como si fuera un test psicológico, y que puede servir para revelar su personalidad.

Martínez Vallvey coincide en parte con esta clasificación, aunque añade una más al distinguir, dentro de las que Martínez Albertos denomina declaraciones, las informativas o noticiosas y las de opinión o declaraciones. Su propuesta tiene cuatro tipos ${ }^{173}$ : las de personalidad, que se centran en la vida del entrevistado; las informativas, cuyo eje principal es interpretar un acontecimiento; las de opinión, que son las que recogen declaraciones en general; y las de cuestionario Marcel Proust, que serían las que tienen forma de test.

José Acosta Montoro considera que siempre una entrevista está provocada por la actualidad, por lo que éste no puede ser el factor que las diferencie. En su propuesta señala cinco tipos, según la naturaleza de la información que la origina. No acepta el cuestionario Marcel Proust, y aporta una novedad al considerar la encuesta y la conferencia de prensa como modelos diferenciados de entrevista ${ }^{174}$.

\footnotetext{
169 Vid. Balsebre, Armand y otros: La entrevista en radio, televisión y prensa. Op. cit., página 284. 170 Vid. Frattini, Eric y Montse Quesada: La entrevista. El arte y la ciencia. Op. cit., página 231. $171 \mathrm{Vid}$. El uso de la entradilla en los textos periodísticos informativos e interpretativos. Op. cit., página 59. 172 Vid. Redacción periodística. Op. cit., páginas 110 y 111.

173 Vid. La entrevista periodística desde el punto de vista conversacional. Op. cit., página 91.

174 Vid. Periodismo y literatura. Op. cit., páginas 107 y 108.
} 
Su clasificación es: la informativa, la de opinión, la de personalidad, las encuestas, y la conferencia de prensa. De ellas, la de personalidad es motivada por la relevancia social del entrevistado, y es la que Núñez Ladevéze considera con más valor literario y psicológico que informativo ${ }^{175}$. La informativa es, según Montserrat Quesada, la que está centrada en el interés que despierta la opinión de un determinado personaje, por lo que debe someterse a las mismas normas de actualidad que en los demás géneros informativos, mientras la entrevista de creación tiene otros componentes aportados por el periodista y se acercan a la estructura de un artículo $^{176}$.

José Javier Muñoz hace una clasificación de las entrevistas según su contenido y su realización ${ }^{177}$ :

1. Por su contenido, las entrevistas pueden ser: de personaje, que son las que tienen como primer factor la figura del entrevistado; las entrevistas de actualidad, cuyo tema central es el desarrollo de una información concreta; y las entrevistas de opinión, que son aquéllas donde lo importante son los puntos de vista de determinados personajes sobre asuntos de actualidad.

2. Por su realización, pueden ser urgentes, si se produce en un diálogo improvisado, y preparadas, cuando son formalmente solicitadas y preparadas. Luis Núñez Ladevéze plantea una tipología de las entrevistas según la forma de preguntar, entre las que distingue las preparadas y las realizadas de forma espontánea, aunque su clasificación más interesante es la que propone en cuanto a las personas entrevistadas ${ }^{178}$ :

1. Entrevista a persona idónea: la que se hace sobre un asunto a quien es su responsable, dentro de la que incluye la rueda de prensa.

2. Entrevista de autoridad: la que se hace sobre cualquier asunto a una persona por su prestigio social o su responsabilidad pública.

3. Encuesta periodística: la que se realiza con una muestra de la población para conocer la opinión pública.

4. Entrevista de personaje popular: cuando se hace a una persona conocida sobre asuntos que nada tienen que ver con la razón de su popularidad.

Otros autores hacen clasificaciones más amplias, como Jorge Halperín que distingue seis tipos de entrevistas teniendo en cuenta lo que busca el periodista y también el grado de presencia del entrevistado ${ }^{179}$, o Guillermina Baena Paz, que propone una clasificación teniendo en cuenta su estructura y su origen ${ }^{180}$.

175 Vid. Introducción al periodismo escrito. Op. cit., página 89.

176 Vid. La entrevista: obra creativa. Op. cit., páginas 11 y 12.

177 Vid. Redacción periodística. Op. cit., páginas 141 y 142.

178 Vid. Introducción al periodismo escrito. Op. cit., página 90 y siguientes.

179 Vid. La entrevista periodística. Intimidades de la conversación pública. Editorial Paidós, Buenos Aires, 1995, página 17.

180 Vid. Géneros periodísticos informativos. Op. cit., página 128 y siguientes. 
Las entrevistas que se enmarcan dentro del periodismo informativo se distinguen, en primer lugar, por el motivo que las originan. Bajo esta perspectiva, hay dos tipos de entrevistas: las de personalidad y las de actualidad, aunque dentro de ellas se pueden distinguir varias modalidades. Las primeras tienen interés por parte del público por la persona entrevistada, independientemente de las cuestiones planteadas por el periodista o la actualidad informativa. Dentro de éstas se incluyen las del "cuestionario Marcel Proust", y las conferencias de prensa, pues es el personaje el motivo de la entrevista. En la de actualidad, lo atractivo para el lector es lo sucedido recientemente, y no la persona que realiza las declaraciones.

Sin embargo, la clasificación más importante es por la forma en que están redactadas. En relación con el modelo de texto, pueden ser entrevistas directas, en las que figuran las preguntas y las respuestas redactadas en primera persona; y las entrevistas creativas, que incorporan en su texto algunas respuestas obtenidas, pero se intercalan dentro de un texto que se aproxima al artículo. Un modelo en el que Montserrat Quesada considera que debe cumplir los dos objetivos principales que la caracterizan: la información, y la estética ${ }^{181}$.

\section{Bibliografía:}

- ABRIL VARGAS, Natividad: Periodismo de opinión. Síntesis, Madrid, 1999.

- ACOSTA MONTORO, José: Periodismo y literatura. Guadarrama, Madrid, 1973 (2 vols.).

- ALDUNATE, Ana Francisca y María José LECAROS: Géneros periodísticos. Pontificia Universidad Católica de Chile, 1989.

- ARFUCH, Leonor: La entrevista, una invención dialógica. Paidós, Barcelona, 1995.

- BAENA PAZ, Guillermina: Géneros periodísticos informativos, Pax México, México D. F., 1990.

- BALSEBRE, Armand, Manuel MATEU y David VIDAL: La entrevista en radio, televisión y prensa. Ediciones Cátedra, Madrid, 1998.

- BERNAL, Sebastiá, y Lluis Albert CHILLÓN: Periodismo informativo de creación, Mitre, Barcelona, 1985.

- BORRAT, Héctor: El periódico, actor político Editorial Gustavo Gili, Barcelona, 1989.

- CASASÚS Gurí, Josep María: Iniciación a la Periodística. Teide, Barcelona, 1988.

- NÚÑEZ LADEVÈZE, Luis: Estilo y Géneros Periodísticos Ariel Comunicación, Barcelona, 1991. 
- CASTEJÓN LARA, Enrique: La verdad condicionada. Corprensa, Baruta (Venezuela), 1992.

- DIEZHANDINO NIETO, María Pilar: El quehacer informativo. Servicio Editorial de la Universidad del País Vasco, Bilbao, 1994.

- DIJK, TEUN A. van: La noticia como discurso. Paidós Comunicación, Barcelona, 1990.

- FRATTINI, Eric y Montserrat QUESADA: La entrevista. El arte y la ciencia. Eudema, Madrid, 1994.

- Gabriel: "Sofismas de distracción". Sala de prensa. Web para profesionales de la comunicación iberoamericanos. Marzo, 2001.

- FERNANDO: Cómo escribir para la prensa. Ibérico Europea de Ediciones, Madrid, 1985.

- JOAQUÍN: Idioma e información. La Lengua Española de la Comunicación. Síntesis, Madrid, 1994.

- JOSEP Lluis: Los titulares en prensa. Mitre, Barcelona, 1982.

- JESÚS: El espectáculo informativo. Akal, Madrid, 1989.

- SUSANA: Géneros periodísticos 1. Periodismo de opinión y discurso. Trillas, México D. F., 1991.

- MARÍA J. Análisis sociolingüístico-textual del lead en los diarios nacionales británicos. Tesis Doctoral inédita. Universidad de La Laguna, 1999.

- ÁLEX: El estilo del periodista. Grupo Santillana de Ediciones, Madrid, 2001.

- JUAN: Periodismo de opinión, Paraninfo, Madrid, 1984.

- JORGE: La entrevista periodística. Intimidades de la conversación pública, Paidós, Buenos Aires-Barcelona, 1995.

- HERNANDO CUADRADO, Luis Alberto: El discurso periodístico. Verbum, Madrid, 2000.

- JORQUES JIMÉNEZ, Daniel: Discurso e información. Estructura de la prensa escrita. Servicio de Publicaciones de la Universidad de Cádiz, Cádiz, 2000.

- LÓPEZ, Manuel: Cómo se fabrican las noticias, Paidós. Barcelona, 1995.

- LÓPEZ HIDALGO, Antonio: La entrevista periodística. Entre la información y la creatividad. Ediciones Libertarias, Madrid, 1997.

- LÓPEZ GARCÍA, Ángel: Escritura e información. Cátedra, Madrid, 1996.

- MARTín VIVALDI, Gonzalo: Curso de Redacción. Paraninfo, Madrid, 1986.

- Géneros periodísticos. Reportaje, crónica, artículo. Análisis diferencial. Paraninfo, Madrid, 1998.

- MARTÍNEZ AGUINAGALDE, Florencio: El uso de la entradilla en los textos periodísticos informativos e interpretativos, Fragua. Madrid, 1997.

- MARTÍNEZ ALBERTOS, José Luis: Redacción Periodística. ATE, Barcelona, 1974.

- Curso General de Redacción Periodística, Mitre, Barcelona, 1983.

- El lenguaje periodístico. Paraninfo, Madrid, 1989. 
- y Luisa SANTAMARÍA SUÁREZ: Manual de estilo, Instituto de Prensa de la Sociedad Interamericana de Prensa, Indianápolis, 1996.

- MARTÍNEZ VALLVEY, Fernando: La entrevista periodística desde el punto de vista conversacional. Publicaciones Universidad Pontificia, Salamanca, 1995.

- Herramientas periodísticas. Librería Cervantes, Salamanca, 1996.

- Cómo se escriben las noticias. Librería Cervantes, Salamanca, 1999.

- MUÑOZ GONZÁLEZ, José Javier: Redacción periodística, Librería Cervantes, Salamanca, 1994.

- NÚÑEZ LADEVÉZE, Luis: Métodos de Redacción Periodística y Fundamentos de Estilo, Síntesis, Madrid, 1993.

- Introducción al periodismo escrito, Ariel Comunicación, Barcelona, 1995.

- PERLADO, José Julio: Diálogos con la cultura. La entrevista periodística. Ediciones Internacionales Universitarias, Barcelona, 1995.

- QUESADA, Montserrat: La entrevista: obra creativa, Mitre. Barcelona, 1984.

- La investigación periodística. Ariel Comunicación, Barcelona, 1987.

- RÍO REYNAGA, Julio del: Teoría y Práctica de los géneros periodísticos informativos. Editorial Diana, México, 1991.

- RODRÍGUEZ BETANCOURT, Miriam: La entrevista periodística y su dimensión literaria. Tauro Ediciones, Madrid, 2001.

- RODRÍGUEZ JIMÉNEZ, Víctor: Manual de Redacción. Paraninfo, Madrid, 1991.

- ROZAS ORTÚZAR, Eliana (edit): Estilo periodístico. Pontificia Universidad Católica de Chile, Santiago de Chile, 1988.

- SÁNCHEZ SÁNCHEZ, José Francisco: La entrevista periodística: introducción práctica, EUNSA, Pamplona, 1993.

- SANTAMARÍA SUÁREZ, Luisa: El comentario periodístico. Los géneros persuasivos, Paraninfo, Madrid, 1990.

- SHERWOOD, Hugh: La entrevista. A.T.E. Barcelona, 1976.

- VILAMOR, José R.: Redacción periodística para la generación digital. Editorial Universitas, Madrid, 2000. 